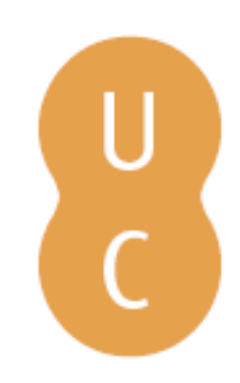

\title{
nombalina
}

\section{Biological and health consequences of human mobility}

$\begin{array}{ll}\text { Autor(es): } & \begin{array}{l}\text { Bielicki, Tadeusz; Lipowicz, Anna; Szklarska, Alicja; Kozie, Sawomir; } \\ \text { opuszaska, Monika; Koodziej, Halina }\end{array}\end{array}$

Publicado por: Imprensa da Universidade de Coimbra

URL

persistente: URI:http://hdl.handle.net/10316.2/38546

DOI: $\quad$ DOI:http://dx.doi.org/10.14195/978-989-26-0773-3_4

Accessed : $\quad$ 26-Apr-2023 13:11:30

A navegação consulta e descarregamento dos títulos inseridos nas Bibliotecas Digitais UC Digitalis, UC Pombalina e UC Impactum, pressupõem a aceitação plena e sem reservas dos Termos e Condições de Uso destas Bibliotecas Digitais, disponíveis em https://digitalis.uc.pt/pt-pt/termos.

Conforme exposto nos referidos Termos e Condições de Uso, o descarregamento de títulos de acesso restrito requer uma licença válida de autorização devendo o utilizador aceder ao(s) documento(s) a partir de um endereço de IP da instituição detentora da supramencionada licença.

Ao utilizador é apenas permitido o descarregamento para uso pessoal, pelo que o emprego do(s) título(s) descarregado(s) para outro fim, designadamente comercial, carece de autorização do respetivo autor ou editor da obra.

Na medida em que todas as obras da UC Digitalis se encontram protegidas pelo Código do Direito de Autor e Direitos Conexos e demais legislação aplicável, toda a cópia, parcial ou total, deste documento, nos casos em que é legalmente admitida, deverá conter ou fazer-se acompanhar por este aviso.

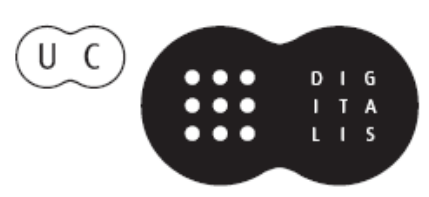




\section{GROWTH AND \\ MATURATION \\ IN HUMAN BIOLOGY \\ AND SPORTS}

FESTSCHRIFT HONORING ROBERT M. MALINA

BY FELLOWS AND COLLEAGUES

PETER TODD KATZMARZYK MANUEL J COELHO E SILVA

EDITORS 


\title{
BIOLOGICAL AND HEALTH CONSEQUENCES OF HUMAN MOBILITY
}

\author{
Tadeusz Bielicki \\ Anna Lipowicz \\ Alicja Szklarska. \\ Stawomir Kozieł \\ Monika Łopuszańska \\ Halina Kołodziej
}

\section{INTRODUCTION}

Social mobility may be of two kinds. Vertical mobility occurs in socially stratified societies and involves a shift of a person's position (up or down) on a scale of attained education or wealth or power or prestige; such scales are often, though not necessarily, interrelated. Vertical mobility may occur between generations, when the shift is measured relative to the position of the subject's parents, or within a single generation, when the subject moves up or down the scale during his/her adult lifetime. Horizontal mobility, in contrast, involves movement either to a different place of residence (e.g. rural-urban, different geographical region, or ethnic group) or to a new marital category. Horizontal mobility does not have to cause a shift in the person's position on any vertical social scale. It is widely recognized that social mobility in one of the factors having a significant indirect impact on a society's biological well-being and health status (Heller et al. 2002).

In Poland an abrupt transition from a socialist command economy to a freemarket system has occurred during the early 1990s. It had a profound impact on virtually all aspects of the society's occupational, educational and demographic structure. More specifically, it has been hypothesized that the recently observed increasing incidence of cardiovascular diseases among younger people in Poland may in part be due to the new patterns of social mobility generated by the country's systemic transformation.

\section{INFLUENCE OF HEIGHT ON ATTAINED LEVEL OF EDUCATION}

The fact that children and adults from upper social strata tend to be taller than their age-mates from lower strata is usually regarded as a phenotypic manifestation of social disparities in living standards (Malina \& Bouchard, 1991). However, the possibility has also been contemplated that in modern industrial societies upward social mobility may be selective with regard to body height, in which case statural differences between social classes might also have a genetic component, even in an ethnically homogenous society. More precisely, the hypothesis postulates that taller individuals are for some reason more likely to move up the scale of educational and/or occupational status than are their shorter peers coming from the same social background. 
Evidence consonant with the above conjecture has been presented and discussed in a number of studies, e.g., Bielicki \& Szklarska (2000) and Szklarska et al. (2007). In these reports an interesting attempt is made to look at this problem. Statures of young adults equated as strictly as possible for social background but differing sharply in educational status achieved by the age of 19 years were compared. Out of a total of 57000 19-year-old conscripts (27,000 in the 1986 and 30,000 in the 1995 cohort), 23 non-overlapping groups were chosen. The 23 groups represent the maximum degree of social homogeneity attainable in the material. Each group was formed of subjects equated for six criteria of social background: education and occupation of parents, number of the subject's siblings and the degree of urbanization. Within each group, men who at the age of 19 years were either secondary-school or college students are, on average, taller than age-mates who come from a very similar social background, but who have never moved beyond the basic trade school. The results demonstrate that among young males equated for social background a significant positive association exists between the subject's stature at the age of 19 years and the educational level attained by him by that age.

\section{NEGATIVE CONSEQUENCES OF DOWNWARD INTRAGENERATIONAL SOCIAL MOBILITY}

Many studies have shown that unemployment has a negative impact on health (Bartley \& Owen, 1996). The loss of one's job not only means a financial loss but also can lead to several secondary difficulties, both physical and psychological: the loss of a structured, fulfilling daily life, of a certain social status, and thereby of a variety of supportive social relationships (Rasky et al., 1996). Martikainen \& Valkonen (1996) showed that unemployment significantly increased the mortality rate among Finnish men from 1981 to 1985. After having controlled for all background variables, they found that relative total mortality among the unemployed was $93 \%$ higher and the relative death rate from circulatory diseases was $54 \%$ higher than it was among men who were employed. Furthermore, unemployment can cause psychological disturbances (Morrell et al., 1994), hypertension and cardiovascular diseases (Cook et al., 1982).

In 2006 the Institute of Anthropology Polish Academy of Sciences took part in a screening program, the Program for the Prevention of Cardiovascular Disease, carried out by the municipal health department of Wroclaw. 452 men and 572 women underwent a medical examination and completed a questionnaire regarding educational level, professional career and life-style elements. All participants were divided into three groups: professionals, skilled and unskilled workers, and currently unemployed individuals. The unemployment status was a recent event, and emerged at most five years before examination, so the third group was recognized as a group experiencing downward social mobility. The Framingham Risk Score (FRS) was used to determine the cardiovascular consequences of employment status. The FRS, derived from the Framingham Heart Study cohort, was designed to predict the risk over a 10-year period of an individual's experiencing one or more of several major adverse coronary events, including mortality due to coronary artery disease and nonfatal myocardial infarction (Kozieł et al., 20l0). 
Regression analyses indicate that occupational status is associated significantly with increased risk of cardiovascular diseases (CVD). This association remains with the inclusion of education level, BMI and/or waistline in the regression, implying that occupation relates to CVD independently. For both sexes FRS mean values regularly increased across the range of occupational groups, with the highest values among unemployed participants (Kozieł et al., 2010).

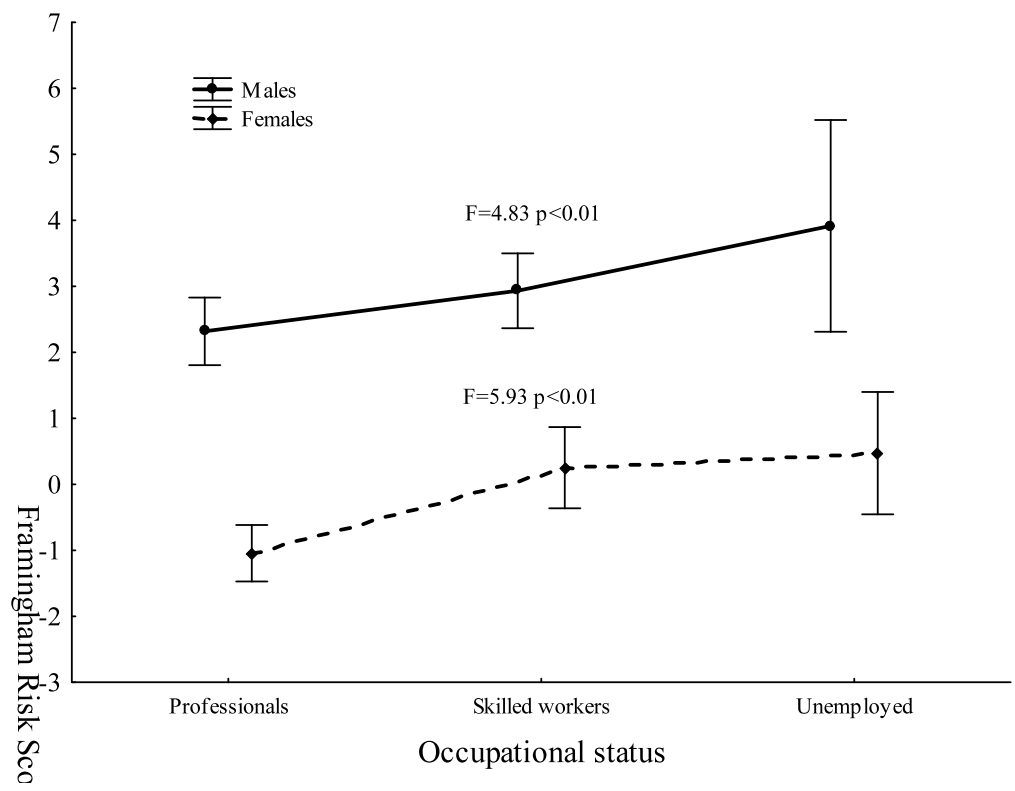

Figure I. Means and standard errors of Framingham Risk Score (FRS) by sex and occupational status. [Source: Kozieł et al., 20l0, Economics and Human Biology; reproduced with permission, Elsevier, license number 3150|||| $29|2|]$.

This study indicates that downward intragenerational social mobility, here analyzed by unemployment status, is associated with an elevated risk of CVD.

\section{MOBILITY BY MARRIAGE}

An example of 'vertical' mobility is change of social position as a result of marriage to a spouse with a discrepant level of education. In general, when the husband is better educated than his wife, she is described as upwardly mobile; when the wife is better educated than her husband, she is described as downwardly mobile. Significant differences in body build, physical fitness and certain health parameters were found between persons moving up and those moving down the social scale through marriage (Lipowicz \& Szklarska, 20l I). Taller women tended to marry men of higher social class, while downwardly mobile men and women were fatter than individuals who 'marry up' (Garn et al. 1989). Women with lesser educated husbands also had a 
more abdominal fat distribution than comparable women with better educated spouses (Lipowicz, 2003).

Also social mobility by marriage significantly affects health status among married Polish men and women. Downwardly mobile women were characterized by higher risk of CVD while upwardly mobile women had a lower risk of CVD compared with individuals in homogamous marriages. The relationship remained significant, when level of education of the individual and lifestyle behaviors were controlled. A similar pattern was observed in men, but the differences were not significant. Poorly educated men who married a better educated wife were an exception; their upwardly mobile marriage did not affect risk of CVD.

Several hypotheses have been proposed for the observed relationship between social mobility and biological condition and health status. Selective social mobility might partly explain the relationship. Among men/women at a constant educational level, slim, taller or healthier persons with better biological condition and healthier lifestyles have more chances of finding better-educated wives/husbands, whereas individuals with health problems or risky behaviours have rather lesseducated spouses.

Assortative mating is an additional consideration (Silventoinen et al., 2003). People tend to choose partners with characteristics that resemble their own socioeconomic group. Given the strong inverse social gradient of health status observed in Poland, it can be hypothesized that men/women who marry up or marry down select spouses with health status and lifestyle behaviors similar to their own. Spousal correlations in fatness and indicators of lifestyle such as diet, drinking and smoking behaviors and frequency of physical activity are significant but vary in magnitude (Macken et al., 2000). It is possible that sharing a common household environment and assimilation of lifestyle in the spouse's social class may influence CVD risk. In Poland, parity changed in the direction of the spouses' socioeconomic environment, leading women to 'imitate' the reproduction model of less-educated women (Lipowicz, 2003). Thus, downwardly mobile Polish women had more children compared with upwardly mobile women. An upwardly mobile husband may experience more favorable lifestyle behaviors related, for example, to diet, alcohol consumption and/or utilization of medical and social services associated with a better educated wife. On the other hand, less educated women may pay inadequate attention to potentially risky behaviors of their husbands. The prevalence of smoking, for example, was higher among men whose wives had only primary school education (Bosma et al., 1995). For women, upward social mobility may have a positive influence on their biological condition and health status through better material conditions of the household.

A better educated wife seems to be "a problem" for poorly educated men. Our results showed that upward social mobility did not affect their health status. It is suggested that better educated wife provokes marital dissatisfaction and disagreements resulting from role conflict or dual roles of wives, what in a consequence impairs their biological condition and health status. 


\section{INTER-GENERATION SOCIAL MOBILITY MODIFIES CHD RISK IN MIDDLE-AGED MEN AND WOMEN}

An important type of inter-generation vertical social mobility is the difference between parents and their adult offspring in the attained level of education. From the point of view of human biologists, and also of students of public health, such mobility is interesting because of the well-known significant effect the individual's position on the educational scale on his/her health status (Lipowicz et al. 2007; Jankowska et al. 2008).

The impact of such inter-generation mobility on health status was recently examined in the course of the Program for Prevention of Cardiovascular Disease conducted by Health Department in Municipal Council in Wroclaw in cooperation with Institute of Anthropology, Polish Academy of Sciences. Because education as a single predictor of social class is more strongly associated with disease than are other indicators (Liberatos et al., 1988), level of father's education was chosen as measure of social position of the individual in childhood.-The detailed effects of inter-generation change in educational status in subgroups of men and women, varying of their father's education level were analyzed.

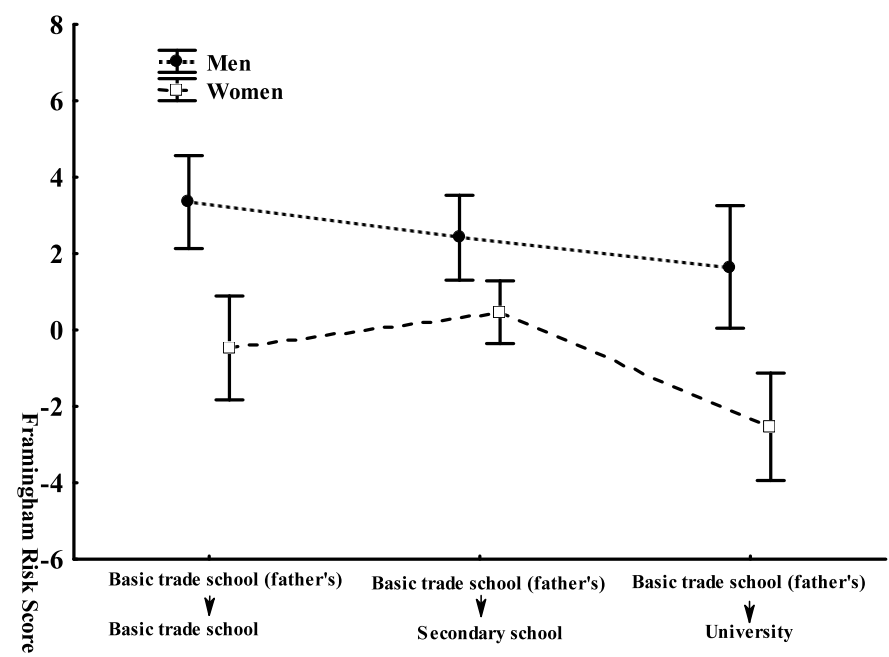

Figure 2. Framingham Risk Scores in Polish men and women according to inter-generational change in educational level (means $\pm 95 \% \mathrm{Cl}$ ). [Source: Jankowska et al. 2008, J Biosoc Sci, 40(3):40 I- I2; permission not required]

Among adult males inter-generation social mobility was shown to be an independent factor affecting the CHD risk as measured by the FRS: irrespective of the level of paternal education, men better educated than their fathers tended to have lower risk scores than those who did not change their position on the educational scale. No such tendency was noted among females. For example, an improvement in educational level among those men whose father had finished basic trade school was followed by a significant decrease of $\mathrm{CHD}$ risk ( $\mathrm{F}=3.25, P=0.04$ ); (see Fig. 2). 
It was also found that social mobility influences several traditional risk factors for cardiovascular disease, which in fact are internal elements of FRS (systolic and diastolic blood pressure, HDL-cholesterol).

A somewhat controversial explanation of the relationship between intergeneration vertical social mobility and health status is the hypothesis of selection. It postulates that persons endowed with higher biological fitness have a better chance to move up on the educational scale relative to their parents; in other words the subject's current health status is an effect of his/her individual chances for social advancement (Cardano et al. 2004). Attention has also been drawn to the possible gradual accumulation of risk factors to which the individual is exposed during his/her lifetime ever since childhood - the phase when living standards are strongly dependent on the parents' education and social position. The lack of relationship between the CVD risk and inter-generation mobility among females is, however, not fully understood. Perhaps some role is played by the fact that in females, health status is more strongly dependent on the social position attained by marriage than upon her own educational attainment (Lipowicz 2003). Moreover, in women the subjective feeling of belonging to a specific social class exerts a stronger influence on the person's health status than does her real position on the social ladder either in childhood or in adult life (Adler et al., 2000). Accumulation of risk throughout the life course has been proposed as an alternative hypothesis. It suggests that exposures or insults gradually accumulate to increase the risk of chronic disease and mortality and that cumulative differential lifetime exposure is the main explanation for the observed socioeconomic differences in risk of disease (Hallqvist et al., 2004). On the other hand, using longitudinal follow-up data, Power et al. (199|) found that health-related mobility did occur but did not explain the health inequalities and pointed out that it was rather lifetime social circumstances that were responsible. Beneficial effects are particularly seen in those men who improved their social position as compared with their fathers.

\section{MIGRATION AS A KIND OF VERTICAL MOBILITY}

Human migration is the movement from place to place of individuals or groups of individuals for the purpose of taking up permanent or temporary residence, usually across a political boundary. Migration occurs at a variety of scales: intercontinental (between continents), intracontinental (between countries on a given continent), and interregional (within countries). People migrate for a variety of reasons. We can recognize a "push" or a "pull" factors. Pull factors - reasons for immigrating (moving into a place) because of something desirable such as a better educational and occupational conditions, freedom, improving living condition, a better food supply access to medical services etc. Push factors - reasons for emigrating (leaving a place) because of a difficulty such as a food shortage, war, discrimination, political or religion persecution, etc. Current migration trends affect living conditions, violence and armed conflicts, environmental problems, a lack of economic perspectives and the growing gap between rich and poor countries (National Geographic Society, 2005).

One of the most significant migration patterns has been rural to urban migration - the movement of people from the countryside to cities in search of opportunities. The extent of rural-urban migration in today's world is enormous. 
Anthropology studies are concerned with the biological consequences of urban-rural migration, especially growth and development and morbidity and mortality (Bogin, 1988). Most empirical studies of rural-to-urban migration find that the health of migrants is better, mortality is lower, and fertility is low compared to rural residents, and their children grow taller (Zielinska, 199।; Klinthäll \& Lindström, 20 I I). The social and economic literature notes that migrants are generally better-educated, higher in socioeconomic status, and younger than rural residents (Butterworth \& Chance, 198I).

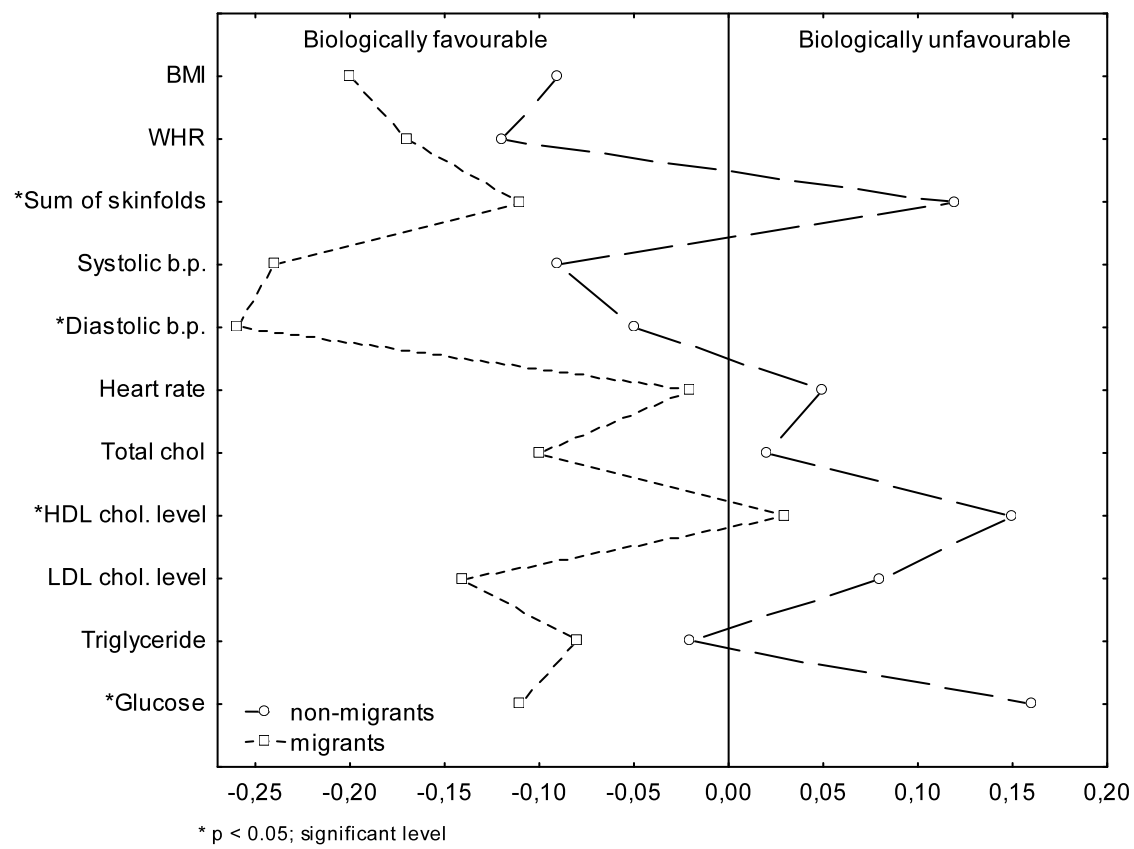

Figure 3. Comparison of men with university education by migrational status. [Source: Szklarska et al. 2008, Am J Hum Biol 20:139-145; reproduced with permission, Wiley \& Sons, license number 3144740 I69983.]

Szklarska and coauthors (2008) compared and analyzed differences in healthrelated biological variables in relation to migration status among inhabitants of the city of Wrocław. In this study, differences in health status between migrant (those who had come to Wrocław at the age of 16 years) and nonmigrant (those who had lived in Wrocław since birth or had come with their parents) inhabitants of Wrocław, Poland were estimated. Comparisons were made based on Borkan's and Norris's profiles (Borkan \& Norris, 1980, Fig. 3).

Male migrants were significantly taller than their peers born in Wrocław. In females, migrants had significantly lower blood pressure and heart rate than nonmigrants. In interpreting the results two possible, not mutually exclusive, 
mechanisms are proposed: selective spatial mobility, and changes toward healthier life style as an adaptation to new urban environment.

Study of second generation migrants provides an opportunity to examine the long effects of migration on a variety of characteristics, including attained young adult height. On the basis of the study of 19-year-old Polish conscripts born in 1976 and examined in 1995, the impact of parental origin (urban or rural) on the attained height of 19 year old males resident in urban centers in Poland was evaluated. Within each of the selected social groups, conscripts whose parents were of rural origin were, on the average, taller than age peers from the same social background but whose parents were of urban origin. These results suggest that region of parent origin has a strong effect on stature of 19 year old males. Corresponding analyses based on only maternal or paternal origin and level of education shown that "post-rural" conscripts tend to be, on average, taller than "urban" conscripts when either maternal or paternal level of education and origin were considered separately. Within each social group with one or two children in the family and with three or more children in the family, there is a trend for mean heights of conscripts born to "post-rural" and "urban" parents to decline from higher to lower levels of parental education. The trend is slightly greater in conscripts from one or two child families (Kołodziej et al., 200I). The trend may be interpreted within two contexts. First, the differences may reflect selective migration with respect to height. Second, migrants may have a greater variety of adaptive strategies to conditions of urban living because of their combined rural and urban experiences and continued access to rural resources (nutritional resources in particular) during the transition to urban living.

The general trends showed that selective migration with respect to body size is not a factor; rather, improved environmental conditions - better hygienic standards of households, quality of diet, regularity of meals and accessibility of health care - are responsible for the growth differences between migrants and non-migrants. It appears likely that the observed differences in height may result from greater adaptability of migrants and/or from the influences of better living conditions.

\section{REFERENCES}

Adler, N.E., Epel, E.S., Castellazzo, G. and Ickovics, J.R., 2000, Relationship of subjective and objective social status with psychological and physiological functioning: preliminary data in healthy white women. Health Psychology, 19, pp. 586-592.

Bartley, M. and Owen, C., 1996, Relationship between socioeconomic status, employment and health during economic change 1973-93. British Medical Journal, 3 I 3, pp. 445-449.

Bielicki, T. and Szklarska, A., 2000, Are social-class differences in stature partly genetic? A hypothesis revisited. American Journal of Human Biology, 12, pp. 97- 101.

Bogin, B., 1988, Rural-urban migration. In Biological Aspects of Human Migration edited by Mascie-Taylor, C.G.N. and Lasker, G.W. (Cambridge: Cambridge University Press), pp. 90- 129. 
Borkan, G. A. and Norris, A. H., 1980, Assessment of biological age using profile of physical parameters, Journal of Gerontology, 35: 177-184.

Bosma, H., Appels, A., Sturmans, F., Grabauskas, V. and Gostautas, A., 1995, Educational level of spouses and risk of mortality: the WHO Kaunas-Rotterdam Intervention Study (KRIS). International Journal of Epidemiology, 24, pp. I I9-26.

Butterworth, D. and Chance, J.K., 1981, Latin American Urbanization. (Cambridge: Cambridge University Press).

Cardano, M., Costa, G. and Demaria, M., 2004, Social mobility and health in the Turin longitudinal study. Social Science and Medicine, 58, pp. I 563- I 574.

Cook, D.G., Cummins, R.O., Bartley, M.J. and Shaper, A.G., 1982, Health of unemployed middle-aged men in Great Britain. Lancet, I, pp. 1290-1294.

Garn, S.M., Sullivan, T.V., and Hawthorne,, V.M., 1989, The education of one spouse and the fatness of the other spouse. American Journal of Human Biology, I, pp. 233-238.

Hallqvist, J., Lynch, J., Bartley, M., Lang, T., and Blane, D., 2004, Can we disentangle life course processes of accumulation, critical period and social mobility? An analysis of disadvantaged socio-economic positions and myocardial infraction in the Stockholm Heart Epidemiology Program. Social Science and Medicine, 58, pp. |555-| 562.

Heller, R.F., McElduff, P., and Edwards, R., 2002, Impact of upward social mobility on population mortality: analysis with routine data. British Medical Journal, 325, pp. |34-137.

Jankowska, E.A., Szklarska, A., Lipowicz, A., Łopuszańska, M., Kozieł, S., and Bielicki, T., 2008, Inter-generation social mobility modifies Framingham Risk Score in Polish middle-aged men, but not in women. Journal of Biosocial Science, 40, 3, pp. 40I412.

Klinthäll, M. and Lindström, M., 20I I, Migration and health: a study of effects of early life experiences and current socio-economic situation on mortality of immigrants in Sweden. Ethnicity \& Health, (Epub ahead of print)

Kołodziej, H., Szklarska, A. and Malina, R.M., 200I, Young adult height of offspring born to rural-to-urban migrant parents and urban-born parents. American Journal of Human Biology, I 3, pp. 30-34.

Kozieł, S., Łopuszańska, M., Szklarska, A., and Lipowicz, A., 2010, The negative health consequences of unemployment: The case of Poland. Economics and Human Biology, 8, pp. 255-260.

Liberatos, P., Link, B.G. and Kelsey, J.L., 1988, The measurement of social class in epidemiology. Epidemiologic Review, 10, pp. 87-121.

Lipowicz, A., 2003, The effect of husbands' education on fatness of wives. American Journal of Human Biology, I 5, pp. I-7.

Lipowicz, A., Kozieł, S., Hulanicka, B., and Kowalisko, A., 2007, SES during childhood and health status in adulthood. The Wroclaw Growth Study. Journal of Biosocial Science, 39, 4 pp. 48I-49I.

Lipowicz, A., Szklarska, A., 20I I, Social mobility by marriage and risk of cardiovascular disease among adults in Southwestern Poland. Annals of Human Biology, 38, 3, pp. 307- 12.

Macken, L.C., Yates B., and Blancher, S., 2000, Concordance of risk factors in female spouses of male patients with coronary heart disease. J Cardiopulm Rehabil, 20, pp. 36।-8. 
Malina, R.M., and Bouchard, C., 1991, Growth, Maturation and Physical Activity. (Champaign, IL.: Human Kinetics).

Martikainen, P.T. and Valkonen, T., 1996, Excess mortality of unemployed men and women during the period of rapidly increasing unemployment. Lancet, 348, pp. 909-912.

Morrell, S., Taylor, R., Quine, S., Kerr, C. and Western, J., 1994, A cohort study of unemployment as a cause of psychological disturbance in Australian youth. Social Sciences \& Medicine, 38, pp. | 553-1564.

National Geographic Society, 2005, Human Migration Guide. www.nationalgeographic.com

Power, C., Manor, O. and Fox, A.J., 1991, Health and Class: The Early Years. (Chapman and Hall, London).

Rasky, E., Stronegger, W.J. and Freidl, W., 1996, Employment status and its healthrelated effects in rural Styria, Austria. Preventive Medicine, I 5, pp. 757-763.

Silventoinen, K., Kaprio, J., Lahelma, E., Viken, R.J., and Rose, R.J., 2003, Assortative mating by body height and BMl: Finnish twins and their spouses. American Journal of Human Biology, I 5, pp. 620-7.

Szklarska, A., Kozieł, S., Bielicki, T., and Malina, R.M., 2007, Influence of height on attained level of education in males at 19 years of age. Journal of Biosocial Science, 39, 4, pp. 575-82.

Szklarska, A., Lipowicz, A., Lopuszanska, M., Bielicki, T., and Koziel, S., 2008, Biological condition of adult migrants and nonmigrants in Wroclaw, Poland. American Journal of Human Biology, 20, pp. 139-145.

Zielinska, D., 1991, Is there a selective rural-urban migration in respect to height and weight? American Journal of Human Biology, 3, pp. 363-368. 